\title{
Brazilian wandering spider accident with sequela of Raynaud phenomenon
}

\section{Acidente por aranha armadeira com sequela do fenômeno Raynaud}

Lidianne Salvatierra ${ }^{1,2}$, Walkyria Rodrigues Ramos ${ }^{3}$

1 Universidade Federal do Tocantins, Coordenação de Biologia, Campus de Araguaína, Tocantins, Brasil

2 Universidade Estadual de Roraima, Programa de Pós-Graduação em Educação, Boa Vista, Roraima, Brasil

${ }^{3}$ Instituto Nacional de Pesquisas da Amazônia, Coordenação de Biodiversidade, Manaus, Amazonas, Brasil

\begin{abstract}
INTRODUCTION: Mild symptoms of envenoming by Phoneutria spiders are local pain, erythema, and edema. Systemic manifestations are uncommon and sequelae have been rarely reported in literature. OBJECTIVE: To describe the case of a young woman bitten by a Phoneutria spider on middle toe of left foot. CASE REPORT: The evaluation was described as a case of moderate complication with Raynaud phenomenon sequelae. The bite site became darker and pain, swelling, and cold sensation persisted for several days along with numbness and desquamation. The clinical examination of the patient also indicated poor circulation on middle toe. After four months from the accident, the wound healed, but the patient experienced persistent pain, which radiated to plantar area, and insistent abnormal blood flow (Raynaud phenomenon) as sequelae. CONCLUSION: This study brings light to sequelae of phoneutrism rarely reported in literature.
\end{abstract}

Keywords: Spider Venoms; Paresthesia; Poisoning; Raynaud Disease.

\section{RESUMO}

INTRODUÇÃO: Os sintomas leves de envenenamento por aranhas Phoneutria são dor local, eritema e edema. Manifestações sistêmicas são incomuns e sequelas raramente são relatadas na literatura. OBJETIVO: Descrever o caso de uma jovem mordida por uma aranha Phoneutria no dedo do meio do pé esquerdo. RELATO DO CASO: Trata-se de um caso de complicação moderada com sequelas do fenômeno Raynaud. O local da mordida tornou-se mais escuro e a dor, o inchaço e a sensação de frio persistiram por vários dias, juntamente com dormência e descamação. $\bigcirc$ exame clínico da paciente também indicou má circulação no dedo médio. Após quatro meses do acidente, a ferida cicatrizou, mas a paciente teve dor constante, que irradiava para a área plantar, e fluxo sanguíneo anormal persistente (fenômeno de Raynaud) como sequelas. CONCLUSÃO: Este estudo elucida as sequelas de foneutrismo raramente relatadas na literatura.

Palavras-chave: Venenos de Aranha; Parestesia; Envenenamento; Doença de Raynaud.

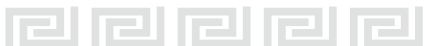

\section{INTRODUCTION}

Phoneutrism caused by Phoneutria spiders (commonly known as Brazilian wandering spider or banana spider) is one of the most important clinical syndromes resulting from bites of these spiders in Brazil ${ }^{1,2,3,4,5}$. They are habitually nocturnal and found in banana plants, palm trees, and bromeliads 6 . Phoneutria spp. are also usually found in shoes, log piles, among discharged matter, and construction materials as well as in banana bundles, which explain the greater frequency of bites in feet and hands ${ }^{7}$. According to the Brazilian Notifiable Diseases Surveillance System (Sistema de Informação de Agravos de Notificação - Sinan), from
2013 to 2016, 11, 860 accidents caused by Phoneutria species were recorded ${ }^{8}$.

The venom of Phoneutria is composed by a high diversity of proteins and peptides, including neurotoxins which act on plasma membrane ion channels and chemical receptors of the neuromuscular control systems of the victim?. The venom can cause depolarization of myofibers and nerve endings at the myoneural junction, activation of the visceral efferent nervous system, causing the circulation of adrenergic neurotransmitters and acetylcholine $e^{8,10,11}$.

In Brazil, the most studied venom of wandering spider species belongs to Phoneutria nigriventer ${ }^{12}$.

\footnotetext{
Correspondence / Correspondência:

Lidianne Salvatierra

Instituto Nacional de Pesquisas da Amazônia, Coordenação de Biodiversidade

Av. André Araújo, 2936. Bairro: Petrópolis. CEP: 69080-971 - Manaus, Amazonas, Brasil

E-mail: lidiannetrigueiro@gmail.com
} 
P. nigriventer venom activates and delays the inactivation of neuronal $\mathrm{Na}^{+}$channels ${ }^{13,14}$. The composition of peptides in the venom of $P$. nigriventer can generate contractures on vascular smooth muscle and can also upsurge capillary permeability by triggering the tissue kallikrein system and stimulating the discharge of nitric oxide $15,16,17,18,19$. It was also showed that the venom lags gastric emptying in rats, in part by the venom-induced catecholamine discharge $\mathrm{e}^{20}$.

Accidents by Phoneutria species cause local pain that may radiate, edema, erythema, paresthesia (burning, numbness, itching), sweating near the site of the bite, hypothermia, tachypnea, bradypnea, blurred vision, pallor, cyanosis, prostarion, generalized muscle fasciculation (involuntary muscle contraction), vomiting, cardiac arrhythmia, tachycardia, poor peripheral perfusion, elevated blood pressure, and, depending on severity, may progress to death $7,8,21,22,23,24$. In many cases, the victim may not notice the bite or chooses not to seek treatment through negligence or difficulties of access to health care facilities.

A clinical epidemiological study including 422 cases of patients from 1984 to 1996 (age ranging from 9 months to 99 years old) bitten by Phoneutria showed that most patients presented only local complaints, mainly pain and edema 7 . Most of the patients (89.8\%) presented mild symptoms, $8.5 \%$ presented moderate envenomation, and only $0.5 \%$ had severe envenomation which was only confirmed in children. In few patients (1.2\%) symptoms of intoxication were not reported. Some of the unusual or acute systemic manifestations, reported so far in the literature, were toxin-induced priapism and acute pulmonary edema followed by death $^{7,25}$

Despite of the medical importance of Phoneutria, there are very few detailed clinico-epidemiological diagnosis and descriptions of systemic envenoming ${ }^{21}$, and, because of reporting failures, there is a gap in epidemiological data. Informations about clinical manifestations in severe cases are unusual, therefore atypical manifestations needs to be reported with precision. Here, the case of an accident caused by the banana spider Phoneutria reidyi with Raynaud phenomenon sequela is reported. All photographs and case information are included with written consent from the patient.

\section{CASE REPORT}

A healthy 23 years old female was bitten on middle toe of the left foot (Figures 1A, 1C; Figure 2A). The victim was in a small ranch near Manaus, Amazonas State, Brazil. The spider was identified as a female Phoneutria reidyi (F. O. Pickard-Cambridge, 1897).

Initially, the spider bite caused a local redness on middle toe, but no significant lesion, erythema or other visible effects developed. Later, the middle toe became swollen, painful, and with local skin discoloration (Figure 1B). During the next few days, the patient experienced mild pain and paresthesia in the middle toe, but did not seek medical advice. In the following days, the toe turned darker (cyanosis). The pain, swelling, and cold sensation on the toe area persisted for several days along with numbness and desquamation around the bite site (Figure 2B). Just after one month from the accident, the victim went to the hospital complaining about the persistent pain, discoloration, and cold sensation on toe. The patient informed the attending physician about the spider bite.
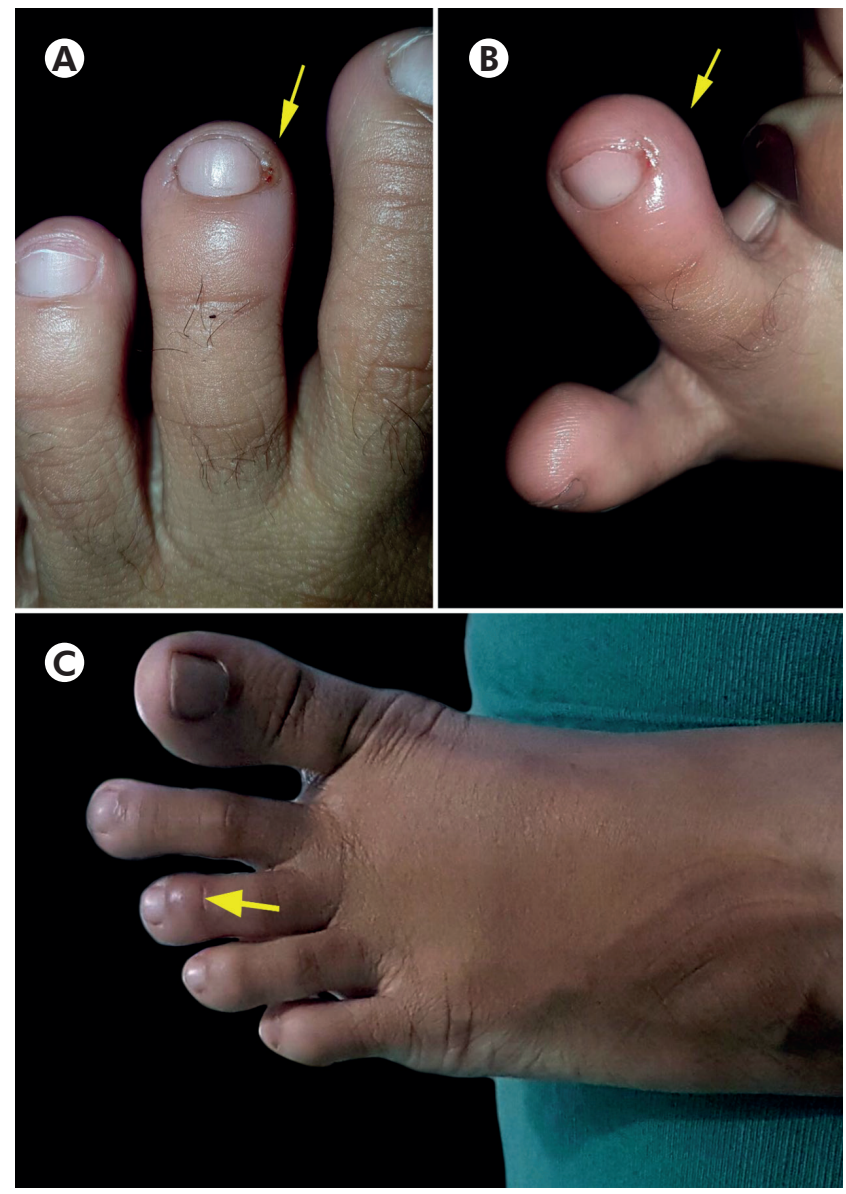

Photos: Lidianne Salvatierra. A: Fang marks on middle toe of left foot; B: Edema; C: Two months after bite.

Figure 1 - Phoneutria reidyi bitten on middle toe of the left foot of a victim from Manaus, Amazonas State, Brazil

A blood test was ordered to check blood sugar and other infections. The laboratory findings were: white blood cell count of $808 \times 10 / \mathrm{mm}^{3}$ (lymphocytes $35.9 \%$, monocytes $8.3 \%$, granulocytes $0.2 \%$, red blood cell count of $4.79 \times 10^{6} / \mathrm{mm}^{3}$, hemoglobin $13.1 \mathrm{~g} / \mathrm{dL}$, platelet $375 \times 10^{3} / \mathrm{mm}^{3}$, hematocrit value of $39.6 \%$, glucose level of $87.4 \mathrm{mg} / \mathrm{dL}$, creatinine value of $0.63 \mathrm{mg} / \mathrm{dL}$, mean corpuscular volume (MCV) of $82.7 \mathrm{fL}$, mean corpuscular hemoglobin $(\mathrm{MCH})$ of $27.3 \mathrm{pg}$, mean corpuscular hemoglobin concentration $(\mathrm{MCHC})$ of $33.1 \%$, red cell distribution width (RDW- SD) of $42 \mathrm{fL}$, and red cell distribution width (RDW- CV) of $14.1 \%$. The blood film was essentially within normal limits. 

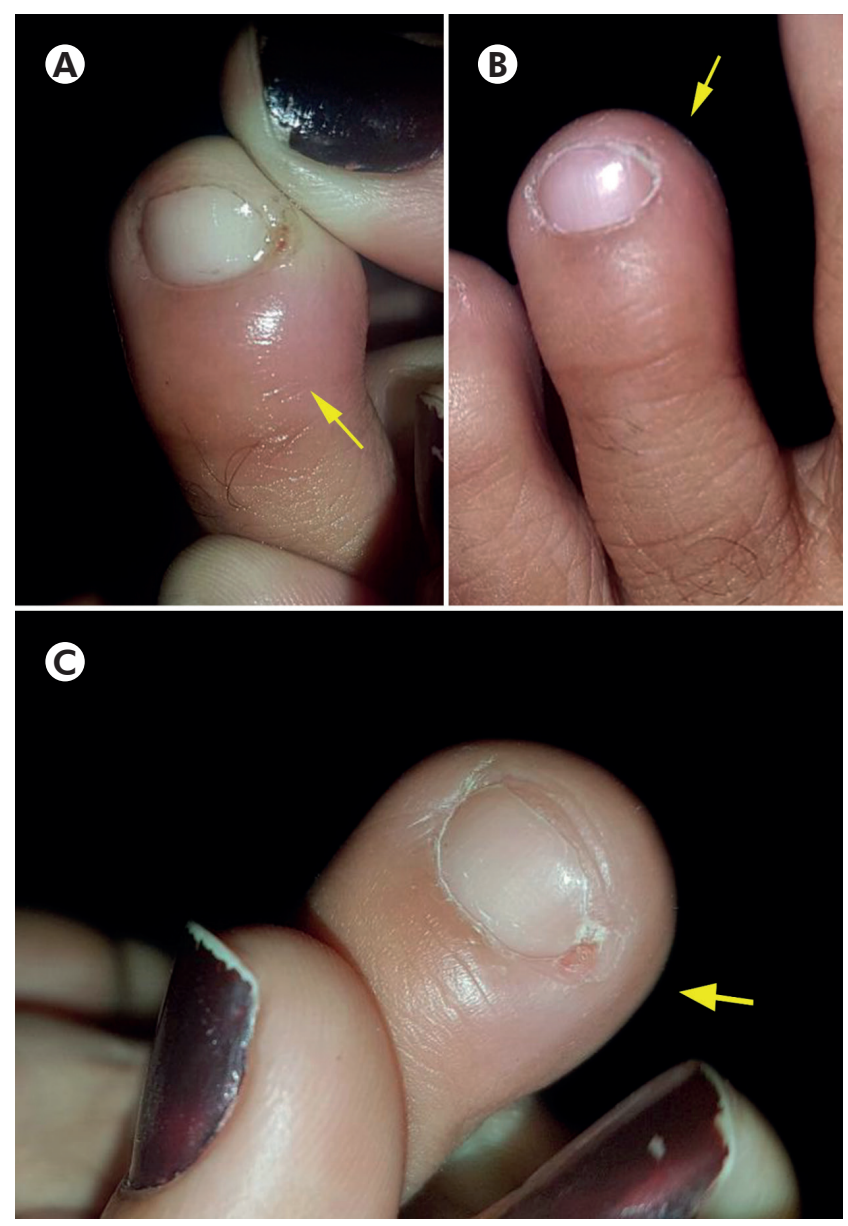

Photos: Lidianne Salvatierra A: Fang marks and edema; B: Desquamation around the bite site; C: Middle toe after four months of bite.

Figure 2 - Middle toe in the left foot of wandering spider victim from Manaus, Amazonas State, Brazil

The clinical examination indicated poor circulation on middle toe. The reduced blood flow was the cause of pain, cold sensation, and pale blue coloration on toe. In order to detect a possible clot or reflux, an aortography, extremity arteriography, venous and arterial duplex vascular ultrasound scan of the lower extremities were carried out and all results were normal. Finally, $x$-ray exam of left leg was performed to detect the cause of pain and swelling and the result was also normal. The exams were performed to rule out the possibility of venous and arterial thrombosis due to the use of oral contraceptives by the patient.

During all this period, the patient received no anti spider venom therapy nor other supportive or symptomatic treatment. The patient applied pequi oil (Caryocar brasiliense) on the bite site following a non-medical advice, and used acetaminophen to relieve pain. The patient experienced persistent pain for eight months, which also radiated to plantar area, and persistent abnormal blood flow (Raynaud phenomenon) as sequelae. After ten months from the accident, the patient followup showed that the wound healed (Figure 2C) and the unusual symptoms ceased without tissue damage.

\section{DISCUSSION}

Phoneutrism systemic manifestations are uncommon, although in severe cases may include arterial hypertension, priapism, and pulmonary edema ${ }^{7,21}$. In this reported case, the signs and symptoms that were developed included pain, edema, poor peripheral perfusion, and paresthesia. The radiated pain and edema observed in the present case are the two most frequent symptoms and emerge from either secondary ischemia to vasospasm or break of myelin wrapping on myofibers. These findings are similar to the previously reported cases of phoneurism $1,2,11,21,22$. However, Raynaud phenomenon, characterized here as persistent low circulation and peripheral neuropathy, has never been reported in the literature as a long-term phoneutrism sequelae.

Raynaud phenomenon is a recurrent vasospasm characterized as the constriction of the small blood vessel (arteries or arterioles) of the extremities that results in occasional changes in skin color of the area, such as pallor, cyanosis or both ${ }^{26}$. The development of Raynaud phenomenon occurs by interactions among nerve fiber endings, smooth myofibers, and endothelium that is induced by soluble mediators settings and is influenced by the patient's surrounding environment ${ }^{27}$, such as venomous animal bites. Raynaud phenomenon may be correlated with and can be the initial symptom of various conditions or disorders, both local and systemic ${ }^{28}$

The symptoms are usually entirely reversible, painless, and typically do not progress to tissue injury. However, it has been documented that some poisonous species of snakes ${ }^{29,30}$ and fish $^{31}$ can cause Raynaud phenomenon. Sathyanathan and Mathew ${ }^{29}$ reported Raynaud phenomenon and gangrene in the opposite limb due snakebite intoxication; and Kularatne and Ratnatunga $^{30}$ described severe Raynaud's syndrome leading to escalating gangrene of distal extremities, and adult respiratory distress syndrome, along with the noted aggravations of acute renal cortical necrosis and haemostatic impairment.

Multiple mechanisms have been suggested for Raynaud phenomenon following venomous animal bites, which the most common include plain toxic response on the muscular tissue of the heart and coagulation disorders, or arterial spasm leading to vasoconstriction induced by some snake venom hemorrhagins or endothelins, for instance ${ }^{32}$.

To the best of our awareness, this is the prime address of a Phoneutria spider accident with Raynaud phenomenon as a sequela. The vasospasm observed in this case evolved to a benign reversible Raynaud phenomenon, but did not lead to tissue damage. Collectively, the present clinical case and those of similar and earlier unusual reports show that venomous animal injuries can cause clinical symptoms that range from patient to patient depending on the physiological response to the venom, given that more sensitive individuals can develop deeper reactions. Some factors, as bite site and underlying 
health problems, may account for this variability in the severity of clinical signs. Also, it is likely that immediate and adequate medical care diminishes the severity of the manifestation and promotes positive results.

In case of accidents, several symptoms of poisoning have been observed, and if the symptoms are not quickly treated, they can evolve to sequelae or even progress to death. Hence, the rigorous identification of the venomous specimens and the lithe clinical care provided to the patient can significantly reduce morbidity and mortality as well as can avoid sequelae.

\section{CONCLUSION}

Accidents with venomous animals are considered a neglected public health issue, and spider bites are especially frequent. The outcomes of spider bites are largely benign but complications can occur. Patients with a suspicion of impending and unusual symptoms should be closely monitored, since they may need more medical attention. Efficient evaluation and inspection and early specific treatment are the main guidance to manage severe cases of intoxication by venomous animals. The present study brings light to sequelae of phoneutrism rarely reported in literature. Further and careful documentation of verified cases, such as this one reported here, will reinforce the medical significance of Brazilian wandering spider bites.

\section{ACKNOWLEDGEMENTS}

The authors would like to thank Coordination for the Improvement of Higher Education Personnel (Coordenação de Aperfeiçoamento de Pessoal de Nível Superior - CAPES) for the postdoctoral grant (Programa Nacional de Pós-Doutorado/Programa de Pós-graduação em Educação da Universidade Estadual de Roraima).

\section{FINANCIAL SUPPORT}

CAPES.

\section{AUTHOR CONTRIBUTIONS}

L.S. and W.R.R. drafted the manuscript. L.S. managed the patient, acquisition of data, and write-up of initial manuscript. W.R.R. worked out almost all of the data collection and technical details, and revised the manuscript. All authors read and approved the final manuscript.

\section{CONFLICTS OF INTEREST}

The authors declare that there is no conflict of interest regarding the publication of this article.

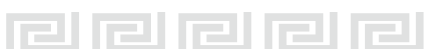

\section{REFERENCES}

1 Antunes E, Málaque CMS. Mecanismo de ação do veneno de Phoneutria e aspectos clínicos do foneutrismo. In: Cardoso JLC, França FOS, Wen FH, Málaque CMS, Haddad Jr V, editores. Animais peçonhentos no Brasil: biologia, clínica e terapêutica dos acidentes. 2. ed. São Paulo: Sarvier; 2009. p. 166-75.

2 Ministério da Saúde (BR). Secretaria de Atenção à Saúde. Departamento de Atenção Básica. Vigilância em saúde: zoonoses. Brasília: Ministério da Saúde; 2009. 224 p. (Série B. Textos básicos de saúde. Cadernos de atenção básica; n. 22).

3 Cristiano MP, Cardoso DC, Raymundo MS. Contextual analysis and epidemiology of spider bite in southern Santa Catarina State, Brazil. Trans R Soc Trop Med Hyg. 2009 Sep; 103(9): 943-8.

4 Lucas S. Spiders in Brazil. Toxicon. $1988 ; 26(9): 759-72$.

5 Lucas SM. Aranhas de interesse médico no Brasil. In: Cardoso JLC, França FOS, Wen FH, Málaque CMS, Haddad Jr V, editores. Animais peçonhentos no Brasil: biologia, clínica e terapêutica dos acidentes. 2. ed. São Paulo: Sarvier; 2009. p. 157-65.
6 Cordeiro FA, Amorim FG, Anjolette FAP, Arantes EC. Arachnids of medical importance in Brazil: main active compounds present in scorpion and spider venoms and tick saliva. J Venom Anim Toxins Incl Trop Dis. 2015 Aug; $21: 24$.

7 Bucaretchi F, Deus Reinaldo CR, Hyslop S, Madureira PR, De Capitani EM, Vieira RJ. A clinico-epidemiological study of bites by spiders of the genus Phoneutria. Rev Inst Med Trop S Paulo. 2000 Feb;42(1):17-21.

8 Silva AM, Bernarde PS, Abreu LC. Accidents with poisonous animals in Brazil by age and sex. J Hum Growth Dev. 2015;25(1):54-62.

9 Lima ME, Figueiredo SG, Matavel A, Nunes KP, Silva CN, Almeida FM, et al. Phoneutria nigriventer venom and toxins: a review. In: Gopalakrishnakone P, Corzo G, Diego-García E, Lima M, editors. Spider Venoms. Dordrecht: Springer; 2015. (Toxinology).

10 Costa SKP, Moreno Jr H, Brain SD, De Nucci G, Antunes E. The effect of Phoneutria nigriventer (armed spider) venom on arterial blood pressure of anaesthetised rats. Eur J Pharmacol. 1996 Mar;298(2): $113-20$. 
11 Vital Brazil O, Leite GB, Fontana MD. Modo de ação da peçonha da aranha armadeira, Phoneutria nigriventer (Keyserling, 1891) nas aurículas isoladas de cobaia. Cienc Cult. 1988 fev;40(2): $181-5$.

12 Medeiros SB, Pereira CDFD, Ribeiro JLS, Fernandes LGG, Medeiros PD, Tourinho SFV. Accidents caused by Phoneutria nigriventer: diagnosis and nursing interventions. J Res Fundam Care. 2013 Oct-Dec;5(4):467-74.

13 Cruz-Höfling MA, Love S, Brook G, Duchen LW. Effects of Phoneutria nigriventer spider venom on mouse peripheral nerve. Q J Exp Physiol. 1985 Oct;70(4):623-40.

14 Fontana MD, Vital-Brazil O. Mode of action of Phoneutria nigriventer spider venom at the isolated phrenic nerve-diaphragm of the rat. Braz J Med Biol Res. 1985;18(4):557-65.

15 Antunes E, Marangoni RA, Brain SD, De Nucci G. Phoneutria nigriventer (armed spider) venom induces increased vascular permeability in rat and rabbit skin in vivo. Toxicon. 1992 Sep;30(9):1011-6.

16 Antunes E, Marangoni RA, Borges NCCT, Hyslop S, Fontana MD, De-Nucci G. Effects of Phoneutria nigriventer venom on rabbit vascular smooth muscle. Braz J Med Biol Res. 1993;26(1): 81-91.

17 Lopes-Martins RAB, Antunes E, Oliva MLV, Sampaio CAM, Burton J, Nucci G. Pharmacological characterization of rabbit corpus cavernosum relaxation mediated by the tissue kallikrein-kinin system. $\mathrm{Br} J$ Pharmacol. $1994 \mathrm{Sep} ; 113(1)$ : $81-6$.

18 Marangoni RA, Antunes E, Brain SD, Nucci G. Activation by Phoneutria nigriventer (armed spider) venom of the tissue kallikrein-kininogen-kinin system in rabbit skin in vivo. Br J Pharmacol. 1993 Jun; 109(2):539-43.

19 Rego E, Bento AC, Lopes-Martins RAB, Antunes E, Novello JC, Marangoni S, et al. Isolation and partial characterization of a polypeptide from Phoneutria nigriventer spider venom that relaxes rabbit corpus cavernosum in vitro. Toxicon. 1996 Oct;34(10): $1141-7$.

20 Bucaretchi F, Collares EF. Effect of Phoneutria nigriventer spider venom on gastric emptying in rats. Braz J Med Biol Res. 1996 Feb;29(2):205-11.
21 Bucaretchi F, Mello SM, Vieira RJ, Mamoni RL, Blotta MHSL, Antunes E, et al. Systemic envenomation caused by the wandering spider Phoneutria nigriventer, with quantification of circulating venom. Clin Toxicol (Phila). 2008 Nov;46(9):885-9.

22 Cupo P, Azevedo-Marques MM, Hering SE. Acidentes por animais peçonhentos: escorpiões e aranhas. Medicina (Ribeirão Preto). 2003 abr-dez;36(2/4):490-7.

23 Lima ME, Borges MH, Verano-Braga T, Torres FS, Montandon GG, Cardoso FL, et al. Some arachnidan peptides with potential medical application. J Venom Anim Toxins Incl Trop Dis. 2010;16(1):8-33.

24 Teixeira CE, Corrado AP, De Nucci G, Antunes E. Role of $\mathrm{Ca}^{2+}$ in vascular smooth muscle contractions induced by Phoneutria nigriventer spider venom. Toxicon. 2004 Jan;43(1):61-8.

25 Troncone LR, Lebrun I, Magnoli F, Yamane T. Biochemical and pharmacological studies on a lethal neurotoxic polypeptide from Phoneutria nigriventer spider venom. Neurochem Res. 1995 Jul;20(7):879-83.

26 Allen EV, Barker NW, Hines Jr EA. Peripheral vascular diseases. 2nd ed. Philadelphia: W. B. Saunders; 1955.

27 McMahan ZH, Wigley FM. Raynaud's phenomenon and digital ischemia: a practical approach to risk stratification, diagnosis and management. Int J Clin Rheumatol. 2010;5(3):355-70.

28 Wigley FM, Flavahan NA. Raynaud's phenomenon. $N$ Engl J Med. 2016 Aug;375(6):556-65.

29 Sathyanathan VP, Mathew MT. Raynaud's phenomenon and gangrene following snake envenomation. J Assoc Physicians India. 1993 Feb;4 1 (2): 122-3.

30 Kularatne SA, Ratnatunga N. Severe systemic effects of Merrem's hump-nosed viper bite. Ceylon Med J. 1999 Dec;44(4):169-70.

31 Carducci M, Mussi A, Leone G, Catricalà C. Raynaud's phenomenon secondary to weever fish stings. Arch Dermatol. 1996 Jul;132(7):838-9.

32 Saadeh AM. Case report: acute myocardial infarction complicating a viper bite. Am J Trop Med Hyg. 2001 May;64(5):280-2. 